\title{
Audit Reports and Value Relevance of Accounting Information: Evidence from Commercial Banks in Nigeria
}

\author{
E. A.L. Ibanichuka ${ }^{1} \&$ Alasin Captain Briggs ${ }^{1}$ \\ ${ }^{1}$ Department of Accountancy, University of Port Harcourt, Rivers State, Nigeria \\ Correspondence: E. A.L. Ibanichuka,Department of Accountancy, University of Port Harcourt, Rivers State, \\ Nigeria
}

Received: January 20, 2018

Accepted: February 20, 2018

Online Published: March 13, 2018

\begin{abstract}
This study examined audit reports and value relevance of accounting information in Nigeria quoted commercial banks. Data was sourced from financial statement of Commercial Banks. Two multiple regressions were formulated to investigate the effect of audit reports and audit characteristics on stock prices of the commercial banks. The data analysis technique employed is the multiple regression model based on Statistical Package for Social Sciences version (22.0). The Durbin-Watson statistics show the presence of multiple serial autocorrelation. The result shows collinearity that corresponds with the Eigen value condition index and variance constants are less than the required number, while the variance inflation factors indicate the absence of auto-correlation. The result from model I found that all the audit report variables have positive impact on value relevance while model II found that audit compensation, audit familiarity and corporate governance have positive effect and audit independence, joint audit and audit size have negative effect on stock prices. The study concludes that the independent variables have significant relationship value relevance of accounting information of Nigeria quoted commercial banks. We recommend that auditing should principle of corporate management beyond the present statue.
\end{abstract}

Keywords: Auditing, Audit Reports, Value Relevance of Accounting Information.

\section{Introduction}

Financial statement users rely on the auditor's report to provide assurance on the company's financial statements. The concern of stakeholder is financial information as reported by auditors should communicate the appropriate information. The concept of value relevance originates from the work of Ball and Brown (1968) and Beaver (1968) investigating whether investor's availability on accounting information is useful information when taking investment decisions. The main objective of value relevance research is to examine whether there is a statistical relationship between financial statement variables as reported by auditors and market variables. The concept of value relevance refers to the ability of accounting information to be reflected in stock values (Francis \& Schipper, 1999). Value relevance has to do with the summarization of accounting information which affects stock values in such a way that the investors can come up with an informed decision, that has to do with an organization. Value relevance is seen as proof of the quality and usefulness of accounting numbers and as such, it can be interpreted as the usefulness of accounting data for decision-making process of investors and its existence is usually by a positive correlation between market values and book values (Takacs, 2012).

In Nigeria Section 296 of CAMA 1990 as amended mandates all public limited companies to make public the financial status of the firm within a specific accounting period. Apart from CAMA, accounting bodies such as 
Institute of Chartered Accountants of Nigerian (ICAN), American Accounting Association (AAA), International Financial Reporting Standard (IFRS) and International Accounting Standard Board (IASB) provides standards for auditing and financial reporting. The principle function and main objective of an audit is to independently assure the credibility of the information contained in an organization's financial statements and to give assurance to shareholders that the financial statement prepared by the management show valid record of how the resources are managed (Moizer, 2005).

The relevance of audit and audit reports has well been documented in literature (Fukukawa and Mack, 2011, Luo, 2011, Hogan and Wilkins, 2008 and Krechel, 2007). Various theories has also been formulated that validate the audit functions in the organization, for instance the policeman theory claim that audit is responsible for searching, discovering and preventing fraud, the lending credibility theory suggest that the major role of an auditor is to add creditability to the financial statement while the agency theory suggests that auditor is appointed in the interest of both the third parties as well as the management( Cleary, 1999; Choi and Jetter, 1998; Abbot, Parker and Peters, 2004; Alsaeed, 2006). The assumption of these theories is that the auditor has valid evidence that supports their opinion and that audit reports can affect to a great extent public perceptions as noted by the fundamentalists as factors that can influence stock prices.

The increasing rate of corporate scandals such as Eron, Worldcom, Parmalat, Command, flowtax, Oceanic Bank, Intercontinental Bank questions the relevant of audit reports. The relevance of audit has well been documented in literature. Studies such as (Azizi et al, 2010; Lin and Hwang, 2010; Arshad et al, 2011) examined the effect of auditing on profitability of quoted firms while other group of scholars examined audit characteristics and performance of firms. The relationship between auditing, audit characteristics and value relevance of accounting information remain a knowledge gap in literature, therefore this study examined the existing relationship between auditing, and audit characteristics on value relevance of accounting information among Nigeria quoted commercial banks. The rest part of this paper are as follows; section two discuses conceptual, theoretical and empirical studies on the effect of auditing and value relevant, section three discusses the methods adopted in the study, section four presents and analyze results while section five concludes and make recommendations from the findings.

\section{Literature Review}

2.1 Conceptual Framework

\subsubsection{Value Relevance}

Value relevance has been defined by various researchers in different ways (Francis \& Schipper, 1999; and Beisland, 2009). Amir, Harris, and Venuti (1993) were the first to define value relevance as the association between accounting numbers and security market values. Other related definitions were subsequently given by Barth; Beaver \& Landsman (2000).Francis and Schipper (1999) interpret value relevance from four different perspectives. First interpretation is that financial statement information affects stock prices by capturing intrinsic share values toward which stock prices drift. The second interpretation is that financial information is value relevant if it contains the variables used in a valuation model or assists in predicting those variables. The third and fourth interpretations considered value relevance as a statistical association between financial information and prices or returns. The forth interpretation of value relevance by Francis and Shipper's (1999) was considered in this study, and as such, defined value relevance of accounting information as the ability of accounting numbers to summarize information that affects the firm's value which can be measured by the aggregate market impact on accounting information.

Beisland (2009) considers value relevance as the ability of financial statement information to capture and summarize firm value. Value relevance is measured as the statistical association between financial statement 
information and stock market values or returns. Earnings and book value are regarded as the basis for firm valuation. However, earnings management affects the reliability and relevance of earnings in ascertaining firms ${ }^{\text {ee }}$ value. On the other hand, information perspective defines value relevance as the usefulness of financial statement information in equity valuation (Nilsson, 2003). Value relevance of accounting information is the ability of any information contained in the financial statements to enable the financial statement users determines the value and performance of the company. Value relevance is also defined as the ability of accounting numbers contained in the financial statements to explain the stock market measures (Beisland, 2009). Accounting data, such as earnings per share, is termed value relevant if it is significantly related to the dependent variable, which may be expressed by price, return or abnormal return (Gjerde, Knivsfla \& Saettem, 2008).

\subsubsection{Audit}

An audit is an objective examination and evaluation of the financial statement of an organization to make sure that the records are a fair and accurate representation of the transactions they claim to represent. It can be done internally by employees of the organization, or externally by an outside firm. When it comes to external auditing, there are two different categories of auditors. First, there is an external or statutory auditor who works independently to evaluate financial reporting, and then there are external cost auditors who evaluate cost statements and sheets to see if they're free of misstatements or fraud (Investopadia, 2017). Both of these types of auditors follow a set of standards different from that of the company or organization hiring them to do the work. Internal auditors, as the name implies, are employed by the company or organization for which they are performing the audit. To the best of their ability, internal auditors provide information to the board, managers, and other stakeholders on the accuracy of their books and the efficacy of their internal systems. Consultant auditors, while not working internally, use the standards of the company they are auditing as opposed to a separate set of standards. These types of auditors are used when an organization doesn't have the resources to audit certain parts of their own operation.

\subsection{Theoretical Framework}

\subsubsection{Policy Man Theory}

The policeman theory claims that an auditor is responsible for searching, discovering, and preventing fraud. The focus of the audit however, has moved towards the verification of the truth and the fairness of the financial statements and the provision of reasonable assurance. The policeman theory is not able to explain fully the role and the purpose of auditing.

\subsubsection{Lending Credibility Theory}

According to the lending credibility theory, the primary function of the audit is to add credibility to the financial statements. Audited financial statements increase the financial statement users' confidence in the financial figures and the faith in management's stewardship. The lending credibility does not explain other functions of performing audit services; this theory is limited in explanatory power.

\subsubsection{Limperg's Theory of Inspired Confidence}

Limperg observed that when the confidence that society has in the effectiveness of the audit and the opinion of the audit is lost, the social usefulness of the audit has destroyed. According to Carmichael (2004), the principles of Limperg's theory are especially relevant in this phase of the development of the audit function. The Theory of Inspired Confidence connects the community's needs for reliability of financial information to the ability of audit techniques to meet these needs, and it stresses the development of the needs of the community and the techniques of auditing in the course of time (Limperg Institute, 1985). 


\subsubsection{Information Theory}

As described in the 'agency theory', financial reporting is central to monitoring purposes. An alternative or complement to the monitoring principle is the information principle, focusing on the provision of information to enable users to take economic decisions. Investors require audited financial information on behalf of their investment decision-making and assessing of expected returns and risks. Investors value the audit as a means of improving the quality of financial information. An audit is also valued as a means of improving the financial data used in internal decision- making. Data that are more accurate will improve the internal decision-making.

\subsubsection{Insurance Theory}

The insurance theory is a more recent explanation for the demand for the role of the audit, that is, the ability to shift responsibility for reported data to auditors lowers the expected loss from litigation to managers, creditors, and other professionals involved in the securities market (Cosserat, 2009). When using audit services, managers and other professionals can demonstrate that they exercised reasonable care.

\subsubsection{The Agency Theory}

Jensen and Meckling (1976) define an agency relationship as a contract under which one or more persons (the principal(s)) engage another person (the agent) to perform some service on their behalf which involves delegating some decision-making authority to the agent. The authors notice that if both parties are utility maximizes (opportunistic behavior); a good reason exists to believe that the agent will not always act in the best interests of the principal. According to Jensen and Meckling (1976) divergence exists between the agent's decisions and those decisions which would maximize the welfare of the principal. Within this principal-agent relationship, owners have an interest in maximizing the value of their shares, whereas managers are more interested in 'private consumption of firm resources' and firm growth.

\subsubsection{Assurance Theory}

An assurance service is a service in which a public accountant expresses a conclusion about the reliability of a written assertion that is the responsibility of another party (Cosserat, 2009). Elder et al. (2010) define an assurance service as an independent professional service that improves the quality of information for decision makers. Individuals responsible for making business decisions seek assurance services to help improve the reliability and relevance of the information used as the basis for their decisions.

\subsubsection{Theories of Stock Market Price}

\section{- The Efficient Market Hypothesis}

The efficient market hypothesis was developed by Fama (1970). The concept of EMH was defined as the market which adjusts speedily to available information. It assumed that the value of the market price of stocks is linear function available information which does not give room for excess return on stocks through the messaging of any market information. The efficiency of stock market has over the years attracted the attention of research in financial economies especially the stock market of the developing countries. This is because the functioning of the capital market is a policy structure for achieving macroeconomic goals.

\section{- The Weak-Form Efficient Market-Hypothesis}

This assumed that the current price of any stock can not contain any valid information to predict and forecast the future price behaviour of the stock. Excess return cannot be earned in the long run by investment strategies based on historic share value of the stock. This implies that fluctuation in stock price, up and down is not the function of information that were not available in the time series but noted that fluctuation of share price is random.

\section{- The Semi-Strong Form Efficient Market-Hypothesis}

This is of the opinion that public available information such as financial statement strategy and past history are fully reflected in current price of the stock price and that no excess returns can be earned by trading on the 
information. This captured some classes of investors by evaluating the earnings and the profit position of the firms before and other investment. This was the case of the stock prices of the banking industry in Nigeria in the banking sector crisis in 2008 that was caused by the margin loans.

- The Strong-Form Efficient Market-Hypothesis

This advocate that all information both public and private is fully reflected in the price and there is no avenue for excess return. The availability of legal barriers to both private and public information renders the strong form of efficient relevant hypothesis except where these laws are ignored.

- The Fundamentalists

The fundamentalist viewed the value of a corporation's stock is determined by expectations regarding future earnings and by the rate at which those earnings are discounted on time. The fundamentalists apply present value principles to the valuation of corporate stock, using dividends, earnings, assets and interest rate to establish the price of stock.

- The Technician

The technical school of taught on the other hand, opposes the fundamentalists' arguments, and claims that stock price behavior can be predicted by the use of financial or economic data. They are of the opinion that stock prices tend to follow definite pattern and each price is influenced by preceding prices, and that successive prices depend on each other. This is contrary to the view of the fundamentalists; Smith (1990) noted that technical analysts engage themselves in studying changes in market prices, the volume of trading and investors' attitude.

\section{- The Behavioural School of Thought}

The behavioural school of finance holds different view from the above schools of thought and opined that market might fail to reflect economic fundamentals under three conditions, which are: The first behavioural condition is irrational behaviour. It holds that investors behave irrationally when they do not correctly process all the available information while forming their expectations of a company's future performance. The second is systematic patterns of behaviour, which hold that even if individual investors decided to buy or sell without consulting economic fundamentals, the impact on share prices would be limited. The third is limits to arbitrage in financial markets ascertain that when investors assume that a company's recent strong performance alone is an indication of future performance; they may start bidding for shares and drive up the price. Some investors might expect a company that surprises the market in one quarter to go on exceeding expectations (Inegbedion, 2009).

- The Macroeconomist School of Thought

The macroeconomic view adopt the usual method of using factor analysis approach to determine the factors affecting asset returns, some scholars have measured macroeconomic factors to explain stock return and found that changes in interest rate are associated with risk. They interpreted the observation to be a reflection of changes in the rate of inflation, given the finding of Fama (1977) that changes in the rate of inflation are fully reflected in interest rates. The macroeconomic approach attempts to examine the sensitivity of stock prices to changes in macroeconomic variables. The approach posits that stock prices are influenced by changes in money supply, interest rate, inflation and other macroeconomic indicators. It employs a general equilibrium approach, stressing the interrelations between sectors as central to the understanding of the persistence and co-movement of macroeconomic time series, based on the economic logic, which suggests that everything does depend on everything else (Iqbal and Mallikarjunappa, 2007).

\section{- Random Walk Theory}

The random walk theory is a component of efficient market hypothesis. It states that current price of any security, fully reflects the information content of its historical sequences of price, Afego (2012). It is built on the premises that investors react instantaneously to information advantage, they have thereby eliminating profit opportunities 
(Dupernex, 2007). Stock price always reflect the information based available and no profit can be made from information based trading (Lo and MacKinlay, 1989). A random walk is known by the fact that prices changes independent of each other (Breadley et al, 2005). Lo and MacKinlay (1999) opined that stock price short-run serial correlations are not zero. They also proposed that in the short-run, prices can gain momentum due to investors jumping on the bandwagon as they see several consecutives periods of some direction price movements with particular stock.

\subsection{Empirical Review}

Gee-Jung and Kwon (2009) conducted an empirical research and established that book value is the most value relevant variable and cash flows have more value relevance than earnings. Further it stated that combined value relevance of book value and cash flows is more value relevant than that of book value and earnings. Frankel and Lee (1998) found that, on average, about 70\% of the variability of share price is jointly explained by accounting information such as current earnings, current book value and earnings forecasts. King and Langli(1998) found that explanatory power of the variables are differs in the accounting systems of the three countries. Book value explains more than earnings in Germany and Norway but less than earnings in United Kingdom. Graham (2000) found that coefficients of these variables are statistically significant for all the countries. The explanatory power of the model ranges from $24 \%$ in Thailand to $90 \%$ in Philippines. Pathirawasm (2010) investigated the value relevance of earnings, book value and return on equity on share price in Colombo Stock Exchange (CSE). Study found that earnings, book value and return on equity have positive value relevance on market value of securities. The most value relevant variable is the earnings while the least value relevant variable is the return on equity in Sri Lanka.

Abiodun (2012) investigated the value relevance of accounting information in corporate Nigeria in which he employed simple descriptive statistics coupled with the logarithmic regression models to examine this interaction between the period 1999 and 2009. The researcher found that earnings isomer value relevant than book values. Suadiye (2012) examined empirically the impact of International Financial Reporting Standards (IFRS) on the value relevance of accounting information in Turkey. The results showed that earnings and book value are, jointly and individually, positively and significantly related to stock price under the two different reporting regimes. Additionally, the results provided that book value of equity is more value relevant than earnings. When two different reporting standards are compared, it is found that the adoption of IFRS increased the value relevance of accounting information for Turkish listed firms.

Chalmers, Clinch \& Godfrey (2011) investigated whether the adoption of IFRS increases the value relevance of accounting information for firms listed on the Australian Securities Exchange. Using a longitudinal study that covers pre-IFRS and post- IFRS periods during 1990-2008, they found that earnings become more value-relevant whereas the book value of equity does not. Tsalavoutas, (2009) examined issues relating to the mandatory adoption of International Financial Reporting Standards (IFRS) by Greek listed companies. They established that there were no change in the value relevance of accounting information between 2004 and 2005. Alali and Foote (2012) examined the value relevance of accounting information under International Financial Reporting Standards (IFRS) in the Abu Dhabi Stock Exchange.. It was documented that earnings scaled by beginning of period price are positively and significantly related to cumulative returns and that earnings per share and book value per share are positively and significantly related to price per share. The study also found that value relevance of accounting information has changed since the market inception in 2000. Kadri, Abdul Aziz, Ibrahim (2010) investigated the value relevance of book value and earnings and the relationship between earnings and operating cash flow of two different financial reporting regimes in Malaysia. They observed that the change in financial reporting regime affects significantly the value relevance of book value and but not 
earnings. While book value and earnings are value relevant during the MASB period, only book value is value relevance during the FRS period.

Kargin (2013) investigated the value relevance of accounting information in pre- and post-financial periods of International Financial Reporting Standards (IFRS) application for Turkish listed firms from 1998 to 2011. The results showed that value relevance of accounting information has improved in the post-IFRS period (2005-2011) considering book values while improvements have not been observed in value relevance of earnings. Hsu, Duha, Cheng (2012) investigated the value relevance of consolidated statements under the ownership based approach of U.S They found that consolidated financial statements based on a broader definition of control provide more useful accounting information than those based only on majority- ownership control. Kim (2013) performed an empirical investigation into the value relevance of information reported by Russian public firms from two distinct perspectives. He documented that prior to 2011; investors relied on information incorporated in the book value of equity. It was also documented that Russian leading firms listed on the London Stock Exchange, that report in accordance with IFRS produce more value- relevant reports compared to their local peers that report under the Russian standards. Palea (2014) Used a sample of Italian firms to investigate whether separate financial statements are useful to capital market investors, and whether International Financial Reporting Standards (IFRS) are more value-relevant than domestic generally accepted accounting principles (GAAP). The study established that separate financial statements are value-relevant, regardless of the accounting standard set. Vijitha and Nimalathasan (2012) used quantitative approaches to examine evidence concerning value relevance of accounting information such as Earning per Share (EPS), Net Assets Value Per Share (NAVPS), and Return On Equity (ROE) and Price Earnings Ratio (P/R) to Share Prices (SP) of manufacturing companies in Colombo Stock Exchange (CSE). The researchers used secondary sources of data collected mainly from financial report of the selected companies of Colombo Stock Exchange (CSE) in Sri Lanka. It was found that the value relevance of accounting information has significant impact on share price and value relevance of accounting information is significantly correlated with share price. Chandrapala (2011) conducted a study to investigate how ownership concentration and firm size impact on value relevance of earnings and book value. The study found that book value is more value relevant than the earnings in Sri Lanka. The three studies reviewed in the preceding paragraphs were all conducted abroad while only earnings and book values were used as explanatory variables. Of the two variables, book value as established as more value relevant. Swart and Negash (2009) also examined the Ohlson (1995) model and documented its validity in explaining share prices using data for 129 firms continuously listed on the Johannesburg Securities Exchange (JSE hereafter), over a twelve year period. The cross sectional results indicate that the Ohlson (1995) model does not establish a significant relationship between year-end share prices and accrual accounting information. However, the panel data least square model resulted in significant and positive relationships between year- end share prices and abnormal earnings, abnormal cash dividends and book value of assets. Abayadeera (2010) applied Ohlsons (1995) Equity Valuation Model (modified for the intangible assets disclosure) to study the value relevance of financial and non-financial information in high-tech industries in Australia with a sample size of 91 companies running through various sectors of the Australian economy. The study documented that book value is the most significant factor and earnings are the least significant factor in deciding share prices in high-tech industries in Australia.

Glezakos, Mylonakis, and Kafouros (2012) studied the impact of earnings and book value in the formulation of stock prices on a sample of 38 companies listed in the Athens Stock Market during the 1996-2008 periods. The results concluded that the joint explanatory power of the above parameters in the formation of stock prices increases over time. The study further examined that the impact of earnings is diminishing, compared to the book value, while investors strive towards analyzing the fundamental parameters of businesses. Mohammad (2012) 
investigates the relationship between accounting information and the value of the companies accepted in Tehran exchange market. The results found that that there is no relationship between accounting information and companies' value (stock value), the study argued that this may be due to lack of efficiency of investment market and inability in using the accounting information by investment market activists. Belesis and Sorrs (2012) investigated the value relevance of accounting information for the Greek listed companies for the period 1995 2009. They examined the way that two accounting variables, earnings and book value, affect the share price. According to their findings from the statistical analysis, the book value and the earnings are value relevant and can explain the share price in the same degree. Also the incremental explanatory power of each variable to a model that contains the other is immaterial. Nayeri (2012) examined the factors affecting the value relevance of accounting information for investors in the Tehran Stock Exchange over the period of six years.The study concluded that that these factors influence on the value relevance of accounting information for investors in Tehran Stock Exchange.

Gjerde, Knivsfla and Saatem (2008) tested the value relevance of financial reporting in Norway over the 40 years before IFRS were introduced. They found that the time trend of overall value relevance has increased significantly after controlling for changes in economic value relevance drivers. Neither the value relevance of the balance sheet nor the income statement has declined over time. Hassan and Saleh (2010) investigated the value relevance of financial instruments disclosure in Malaysia based on Malaysian Accounting Standard Board (MASB). Their results indicated that disclosure quality of financial instruments information is value relevant. However, the relationship is less positive in the period after the MASB become mandatory. Further evidence suggests the less positive relationship is not caused by bad news but is caused by the disclosure quality of risks. Karunarathne and Rajapakse (2010) conducted a study to investigate the value relevance of financial information that extracted from financial statement directly or indirectly. Specifically, the study considered the value relevance of earnings and cash flows in stock prices. In addition, the study pays attention on the firm size effect on value relevance. Hellstrom (2005) investigated the value relevance of accounting information in the Czech Republic in 1994-2001. The results showed that the value relevance of accounting information indeed is lower in the Czech Republic than in Sweden. The results, however, indicate an improvement in the quality of the Czech financial accounting information during the research period. Khanagha (2011) embarked on a study to identify the value relevance of accounting information in two selected countries which could describe the effect of adapting to IFRS on value relevance of accounting information in these countries. The results obtained from a combination of regression and portfolio approaches, showed that accounting information is value relevant in Bahrain and the United Arab Emirates (UAE) stock market. Khodadadi and Emami (2009) set up their study to determine the best method of panel data analysis for use in Ohlson (1995) predicting model. The research results showed that the first method has better performance in predicting abnormal earnings by Ohlson (1995) model. Ariff, Alfred, and Patricia (1997) reported the relationship between earnings and share prices. The results showed that unexpected earnings changes are significantly associated with share price changes. The results are adjusted for risk differences by using a non-synchronous correction procedure to remove thin-trading bias. Oyerinde (2009) investigated the value relevance of accounting data in the Nigerian Stock Market. The primary objective of the study is to determine if there is a relationship between accounting numbers and share prices in the Nigerian Stock Market. The value relevance of accounting data was measured by the correlation coefficient between stock prices and some accounting numbers. The researcher used linear regression to estimate the model of the study. Oyerinde (2011) extended her study two years after to investigate the value relevance of accounting data in the Nigerian stock market partly with a view to determining whether accounting information has the ability to capture data that affect share prices of firms listed on the NSE. The study found that Dividends 
are the most widely used accounting information for investment decisions in Nigeria, followed by earnings and net book value. Maradun (2009) found that $t$ ere is a positive relationship as well as significant impact between earnings and share price of building materials firms in Nigeria. Chang, Chen, Su and Chang (2008) investigated the relationship between stock prices and earnings per share (EPS) using panel co integration procedure. Furthermore, they considered whether stock prices respond to EPS under the different level of growth rate of operating revenue. The empirical result indicated that co integration relationship existed between stock prices and EPS in the long-run. Furthermore, the study found that for the firm with a high level of growth rate, EPS has less power in explaining the stock prices; however, for the firm with a low level of growth rate, EPS has a strong impact in stock prices. Omura (2005) examined the value relevance of annually-reported book values of net assets, earnings and dividends to the year-end market values of five Japanese firms between 1950 and 2004 (a period of 54 years). One of the significant findings of the study was that, in the long run, the book value of net assets has relevance for market value in the five Japanese firms examined.

Alali and Foote (2012) examined the value relevance of accounting information under International Financial Reporting Standards (IFRS) in the Abu Dhabi Stock Exchange (ADX, henceforth). Based on models developed by Easton and Harris (1991), and Ohlson (1995) and using monthly market data from 2000 to 2006, this paper investigated the value relevance of accounting information of firms traded on the ADX. It was documented that earnings scaled by beginning of $\mathrm{p}$ riod price are positively and significantly related to cumulative returns and that earnings per share and book value per share are positively and significantly related to price per share. The study also found that value relevance of accounting information has changed since the market inception in 2000. Clarkson, Hanna, Richardson \& Thompson (2011) investigated the impact of IFRS adoption in Europe and Australia on the relevance of book value and earnings for equity valuation. Using a sample of 3,488 firms that initially adopted International Financial Reporting Standards (IFRS) in 2005, they established that IFRS enhances comparability.

Hsu, Duha, \& Cheng (2012) investigated the value relevance of consolidated statements under the ownership based approach of U.S. Accounting Research Bulletin No. 51 (ARB 51) and the control-based approach of International Accounting Standard No. 27 (IAS 27). The results of their study showed that consolidated financial statements based on a broader definition of control provide more useful accounting information than those based only on majority-ownership control. Jermakowicz, Prather-Kinsey and Wulf (2007) examined the challenges and benefits, including value relevance, of the adoption of IFRS by DAX-30 companies, the German premium stock market. The researchers used regression to measure the value relevance of book values of earnings and equity in explaining market values of DAX-30 companies during the period 1995-2004. Using 265 observations, they found that adopting IFRS or US Generally Accepted Accounting Principles or cross- listing on the New York Stock Exchange significantly increases the value relevance of earnings relative to market prices.

Kadri, Abdul Aziz, Ibrahim (2010) investigated the value relevance of book value and earnings and the relationship between earnings and operating cash flow of two different financial reporting regimes in Malaysia. They observed that the change in financial reporting regime affects significantly the value relevance of book value and but not earnings. While book value and earnings are value relevant during the MASB period, only book value is value relevance during the FRS period. Kim (2013) performed an empirical investigation into the value relevance of information reported by Russian public firms from two distinct perspectives. He documented that prior to 2011; investors relied on information incorporated in the book value of equity. The value relevance of reported earnings, however, is different for "growth" versus "value" stocks. It was also documented that Russian leading firms listed on the London Stock Exchange, that report in accordance with IFRS produce more value- relevant reports compared to their local peers that report under the Russian standards. 
Kouser and Azeem (2011) conducted a study that focused on the statistical power to explain changes in share price and intervening impact of IFRS adoption using two independent variables, which are book value of equity and earnings. They adopted a year by year OLS regression for their analysis covering eight year period (2002 to 2009). The study showed almost similar results in Pakistan as earlier studies of different countries empirically proved. It is proved the high relevance of accounting numbers was the result of high quality investor oriented financial quality. Olugbenga \& Atanda (2014) conducted a research to examine the value relevance of accounting information of quoted companies in Nigeria using a trend analysis. Secondary data were sourced from the Nigerian Stock Exchange FactBook; Annual Financial Reports of Sixty six (66) quoted companies consisting of financial and non-financial Firms in Nigeria and the Nigerian Stock Market annual data. The Ordinary Least Square (OLS) regression method was employed in the analysis. The study revealed that accounting information on quoted companies in Nigeria is value relevant. The above literature does not examine the effect of auditing on value relevance of accounting information.

\section{Research Methodology}

This study examined the impact of auditing and value relevance of accounting information of commercial banks in Nigeria. The relevant data were sourced from financial statement of commercial banks. Time series data were used and econometric method of data analyses which involves Ordinary Least Square (OLS) were employed. The multiple regressions formulated in this study are based on the various schools of thought on the effect of auditing on performance of quoted firms.

Model I: Audit Report

$\mathrm{STP}=\mathrm{f}(\mathrm{FR}, \mathrm{TA}, \mathrm{LR}, \mathrm{FF}, \mathrm{CG})$

Transforming equation 1 above to econometric method, we have:

$\mathrm{STP}=\beta 0+\beta 1 \mathrm{FR}+\beta 2 \mathrm{TA}+\beta 3 \mathrm{LR}+\beta 4 \mathrm{FF}+\beta 5 \mathrm{CG}+\mu$

\section{Model II: AUDIT CHARACTERISTICS}

$\mathrm{STP}=\mathrm{f}(\mathrm{AC}, \mathrm{AI}, \mathrm{AF}, \mathrm{JA}, \mathrm{CG}, \mathrm{LR})$

Transforming equation 1 above to econometric method, we have:

$\mathrm{STP}=\beta 0+\beta 1 \mathrm{AC}+\beta 2 \mathrm{AI}+\beta 3 \mathrm{AF}+\beta 4 \mathrm{JA}+\beta 5 \mathrm{CG}+\beta 6 \mathrm{~B} 4 \quad+\mu \ldots . .(4)$

Where:

$\mathrm{STP}=$ Stock prices of commercial banks listed on the floor of Nigeria stock of exchange

$\mathrm{FR}=$ Financial report proxy by profit after tax

$\mathrm{TA}=$ Total assets

$\mathrm{LR}=$ Leverage ratio

$\mathrm{FF}=$ Financial fraud proxy by dummy variable 1 for evidence of fraud and 0 for no fraud

$\mathrm{CG}=$ Corporate governance proxy by dummy variable

$\mathrm{AC}=$ Audit compensation proxy by amount paid to audit firm

$\mathrm{AI}=$ Audit independence proxy by dummy variable

$\mathrm{AF}=$ Audit familiarity proxy by 1 for repetition of audit and 0 for not repetition

$\mathrm{JA}=$ Joint audit

B4 = The big four audit firms 1 for the use of one of the four audit firms and 0 for none.

$\mu=$ Error Term

$\beta 1-\beta 5=$ Coefficient of Independent Variables to the Dependent Variable 
$\beta 0=$ Regression Intercept.

Statistical Approach

The statistical approaches used in this study include:

(i) Coefficient of Determination (R2): This is used to measure the extent to which the independent variables in the model can explain changes on the dependent variable.

(ii) Correlation Coefficient (R): This measures the strength and the extent to which the dependent and the independent variable are related.

(iii) T-Test: This is used to measure the significance of the independent variables to the dependent variable and the hypothesis was tested at $5 \%$ level of significance and at $95 \%$ confidence interval. The hypothesis for this test is stated as follows:

Null Hypotheses; H0: $\beta=0$, (Statistically not significant)

Alternate Hypotheses; H1: $\beta \neq 0$. (Statistically Significant)

And the decision rule states that "H0" should be rejected when T-statistics is greater than the critical value. But when the T-statistics is lower than the critical value, the "H0" is accepted with its conclusion.

(iv) F-Test: This is used to find out the overall significance of the regression model at 5\% level of significance. The hypothesis for this test is stated as:

Null Hypotheses; H0: $\beta 1-\beta 6=0$ (all slope coefficients are equal to zero)

Alternative Hypotheses: $\mathrm{H} 0: \beta 1-\beta 6 \neq 0$ (all slope coefficients are not equal to zero)

The decision rule for this test is that " $\mathrm{H} 0$ " should be rejected when F-statistics is greater than the critical value of F. but when the F-statistics is lower, then the "H0" is accepted while the $\mathrm{H} 1$ is rejected.

(v) Test for Autocorrelation

The Durbin Watson statistics is used in this research to test for the presence of autocorrelation. When there is presence of autocorrelation, the First order autoregressive scheme will be employed to correct it. The hypotheses states that:

$\mathrm{H} 0: \mathrm{P}=0$ (There is serial independence in the errors)

$\mathrm{H} 1: \mathrm{P}>0$ (There is first order (AR) positive autocorrelation.

When the Durbin Watson Statistics (DW-Stat) is lesser than lower Durbin Watson (DL), the null hypothesis (H0) is being rejected but if the Durbin Watson statistics is greater than the upper Durbin Watson (Du), the null (H0) is then accepted.

Methods of Data Analysis

In order to have a proper analysis of the data sourced, the use of Multiple Regression and Statistical Package for Social Sciences (SPSS) shall also be used. It will also employ descriptive statistics such as graphs and bar charts in illustrating the trends of the variables within the time covered in this study.

\section{Presentation of Results and Discussion of Findings}

Test of Colinearity and Autocorrelation of the Variables: Model I

Table 1 Tolerance and Variance inflation factor (VIF)

\begin{tabular}{lll}
\hline & Tolerance & VIF \\
\hline FR & .986 & 1.015 \\
\hline TA & .865 & 1.157 \\
\hline LR & .940 & 1.064 \\
\hline FF & .835 & 1.197 \\
\hline CG & .821 & 3.629 \\
\hline
\end{tabular}

Source: Extract from SPSS 20.0 
Table 1 shows a tolerance of above 0.1 inverse to the rule of the thumb which is contrary to the rule for testing multicolinearity on tolerance while the variables of the variance inflation factor (VIFs) which are satisfies the threshold of being above 0.5 and less than 10 .

Table 2 Durbin Watson and Autocorrelation Test

\begin{tabular}{lllllllll}
\hline Variables & Eigen Value & Condition Index & Constant & A & B & C & D & E \\
\hline 1 & 4.250 & 1.000 & .00 & .00 & .00 & .01 & .01 & .04 \\
\hline 2 & .501 & 2.913 & .00 & .00 & .02 & .21 & .04 & .03 \\
\hline 3 & .153 & 5.276 & .00 & .02 & .14 & .12 & .86 & .04 \\
\hline 4 & .080 & 7.301 & .01 & .26 & .58 & .31 & .03 & .03 \\
\hline 5 & .016 & 16.080 & .98 & .72 & .26 & .35 & .06 & .04 \\
\hline
\end{tabular}

Source: Extract from SPSS 20.0

Durbin Watson Model 2.26

$\mathrm{FR}=$ Financial Report

TA $=$ Total Assets

LR = Leverage Ratio

$\mathrm{FF} \quad=$ Financial Fraud

$\mathrm{CG}=$ Corporate Governance

The table above illustrated a co linearity and autocorrelation; the results found that the Eigen values that correspond with the highest condition index and variance constants are less than 0.5 rule of the thumb. The Durbin Watson statistics of 2.264 shows the absence of multicolinearity, portraying a significant relationship between the dependent and the independent variables in the model.

Table 3: Effect Audit Report on Value Relevance of Accounting Information

\begin{tabular}{llllll}
\hline Variables Coefficient & A & B & C & D & E \\
\hline Unstandardized Beta & 1.683 & .370 & .446 & 18.525 & .256 \\
\hline Std Error & 1.442 & .264 & .225 & 12.662 & .388 \\
\hline Standardized Beta & .266 & .341 & .463 & .363 & .256 \\
\hline T-Statistics & 1.168 & 1.398 & 1.981 & 1.463 & -.162 \\
\hline Sig. T & .266 & .187 & .071 & .169 & -.898 \\
\hline
\end{tabular}

Constant $\alpha 0=19.964$, T-test 5.529, Sig t $=.0 .000$

Source: $\quad$ Extract from SPSS 20.0

The table above shows the relationship between the dependent and the independent variables in the study. The unstandardardize and unstandardize beta coefficient of the variables as shown in the above table prove all the independent variables have positive relationship with the dependent variable which means that increase on the independent variables will lead to increase on the dependent variable. However the t-statistics and the significant proved the independent variables are statistically not significant in explaining changes on the dependent variable. Test of Colinearity and Autocorrelation of the Variables 
Table 4: Tolerance and Variance inflation factor (VIF) Model II

\begin{tabular}{lll}
\hline & Tolerance & VIF \\
\hline AC & .865 & 1.015 \\
\hline AI & .327 & 1.157 \\
\hline AF & .661 & 1.064 \\
\hline JA & .854 & 1.197 \\
\hline CG & .298 & 3.629 \\
\hline LR & .802 & 3.567 \\
\hline
\end{tabular}

Source: $\quad$ Extract from SPSS 20.0

Table 4.4 shows a tolerance of above 0.1 inverse to the rule of the thumb which is contrary to the rule for testing multicolinearity on tolerance while variables of the variance inflation factor (VIFs) which are satisfies the threshold of being above 0.5 and less than 10 . This finding confirm the finding in model one above.

Table 5: Durbin Watson and autocorrelation test

\begin{tabular}{lllllllll}
\hline Variables & Eigen Value & condition Index & constant & A & B & C & D & E \\
\hline 1 & 4.857 & 1.000 & .00 & .00 & .00 & .01 & .01 & .00 \\
\hline 2 & .574 & 2.910 & .00 & .01 & .00 & .18 & .22 & .02 \\
\hline 3 & .384 & 3.556 & .00 & .00 & .01 & .03 & .55 & .08 \\
\hline 4 & .100 & 3.976 & .00 & .81 & .03 & .35 & .03 & .02 \\
\hline 5 & .059 & 9.068 & .40 & .04 & .09 & .43 & .19 & .38 \\
\hline 6 & .027 & 13.502 & .59 & .14 & .87 & 01 & .00 & .50 \\
\hline
\end{tabular}

Source: $\quad$ Extract from SPSS 20.0

Durbin Watson Model

$\begin{array}{ll}\mathrm{A} & =\text { Audit compensation } \\ \mathrm{B} & =\text { Audit Independent } \\ \mathrm{C} & =\text { Audit familiarity } \\ \mathrm{D} & =\text { joint audit } \\ \mathrm{E} & =\text { Corporate governance } \\ \mathrm{F} & =\mathrm{B} 4\end{array}$

The table above illustrated a co linearity and autocorrelation; the results found that the Eigen values that correspond with the highest condition index and variance constants are less than 0.5 rule of the thumb. The Durbin Watson statistics of 2.043 shows the absence of multicolinearity, portraying a significant relationship between the dependent and the independent variables in the model. This result confirm the finding in model one as presented in table 4.2 
Table 6: Effect of Audit Characteristics on Value Relevance

\begin{tabular}{lllllll}
\hline Variables Coefficient & A & B & C & D & E & F \\
\hline Unstandardized Beta & .304 & -.073 & -.246 & 3.145 & -.063 & .063 \\
\hline Std Error & .402 & 1.143 & .426 & 16.015 & .849 & .022 \\
\hline Standardized Beta & .235 & -.032 & -.205 & .062 & -.040 & .481 \\
\hline T-Test & .752 & -.064 & -.577 & .196 & -.075 & .897 \\
\hline Sig. T & .466 & .950 & .576 & .848 & .942 & 0.414 \\
\hline Constant $\alpha 0=62.013$, T-test $1.883, \mathrm{Sig} \mathrm{t}=.086$ & & & & \\
\hline
\end{tabular}

Source: $\quad$ Extract from SPSS 20.0

The regression result presented in the above table shows that audit compensation, joint audit, the big 4 have positive effect on stock prices of the commercial banks while audit independence, audit familiarity and corporate governance have negative relationship with the dependent variable. However the t-statistics and the significant proved the independent variables are statistically not significant in explaining changes on the dependent variable.

Table 7: Regression Summary

\begin{tabular}{lll}
\hline Model Summary & Model I & Model II \\
\hline $\mathrm{R}$ & .620 & .869 \\
\hline $\mathrm{R} 2$ & .523 & .642 \\
\hline Adj. R2 & .493 & .437 \\
\hline F-Ratio & 4.875 & 3.184 \\
\hline Sig F & .0 .000 & .0041 \\
\hline
\end{tabular}

Source: $\quad$ Extract from SPSS 20.0

The estimated regression models is summarized in the table above, Model I shows a correlation coefficient of $62.0 \%$, and an R2 of 52.3\%, adjusted R2 $49.3 \%$ which means that $62.0 \%$ and $49.3 \%$ variation on stock prices of the commercial banks can be explained by the financial audit report variables examined in the study, and F-ratio of 4.875 with the probability of .000 which justifies the model. Model II found a correlation coefficient of $86.9 \%$ and R2 of $64.2 \%$, adjusted R2 of $43.7 \%$, the f-ratio and probability of 3.184 and the probability of .004 validate the model.

\section{Discussion of Findings}

The objective of model I was to investigate the effect of reports on the value relevance of accounting information in Nigeria commercial banks. Evidence from the results proved that all the independent variables have positive relationship with value relevance of accounting information which is proxy by the stock prices of the quoted commercial banks. This finding confirms the expectation of the results and validates the important of audit reports and its effect on investment decision making of financial users such as investors. The finding also confirms the fundamentalist opinion that information content of financial statement affects stock prices of quoted firms. The finding of this study is in line with the findings of Gee-Jung and Kwon (2009) who found that combined value relevance of book value and cash flows is more value relevant than that of book value and earnings, Pathirawasm (2010) who found that earnings, book value and return on equity have positive value relevance on market value of securities. The most value relevant variable is the earnings while the least value relevant variable is the return on equity in Sri Lanka, Abiodun (2012) who found that earnings isomer value relevant than book values and the findings of Suadiye (2012) whose results showed that earnings and book value are, jointly and individually, positively and significantly related to stock price under the two different reporting regimes. 
Model II was formulated to examine the relationship between auditors' characteristics on value relevance of accounting information. The results as shown the table reveal that audit compensation, auditors independence and auditors size have positive effect on the stock prices of the commercial banks while audit independence, joint audit and corporate governance have negative effect on stock prices of the commercial banks. The positive effect of the variables confirm to the a-priori expectation of the results, confirms the objective audit reports while the negative effect is contrary to the expectations of the results and could be trace to internal and external factors that influence auditing in the banking industry. The positive effect confirm the findings of Kargin (2013) whose results showed that value relevance of accounting information has improved in the post-IFRS period, Vijitha and Nimalathasan (2012) whose study found that the value relevance of accounting information has significant impact on share price and value relevance of accounting information is significantly correlated with share price and the findings of Chandrapala (2011) who found that book value is more value relevant than the earnings in Sri Lanka.

\section{Conclusion and Recommendation}

\subsection{Conclusion}

The objective of the audit and auditing is to examine financial statements of corporate firms to ascertain whether the financial statement presented by the management have true financial position of a firm and if changes in financial position in conform to generally accepted accounting principles. From the models formulated and the findings as presented above, we conclude that auditing have positive and significant effect on the value relevance of accounting information of the quoted commercial banks in Nigeria

\subsection{Recommendation}

- Auditing, the principle of auditing and audit function should be made effective and used as a mechanism to value relevance of accounting information in quoted firms in Nigeria.

- All factors internal and external that challenge the effectiveness of audit functions should be eliminated and policies to encourage audit independence should be encouraged.

- Apart from external laws such as contain in CAMA in respect to audit, there is need to incorporate auditing as internal management system beyond the level it is now in the firms.

- Commercial banks should adopt the IFRS for in preparation of financial statement which will boost confidence to the financial users. Employing of qualified personnel to reduce the risk of transactions and ensure proper keeping of records to attract investors.

- Commercial banks should understand their duties and the duties of the auditor. They should understand that the auditor is a spot check of information, not exhaustive review of all financial transactions. Further, the auditor is charged with determining the accuracy of the financial statements only in all material aspect.

\section{References}

Abbott, L. J., Parker, S., \& Peters, G. F., (2004). Audit Committee Characteristics and Restatements. Auditing: A Journal of Practice and Theory, 23(1), 69-87.

Abdullahi, I. B, Lawal, W. A, and Ibrahim, R. O (2012). An empirical Estimation of Average Return in the Nigerian Stock Market. International Journal of Social Sciences and Education, 2: 67 - 73

Abiodun, B. Y. (2012). Significance of Accounting Information on Corporate Values of firms in Nigeria, Research Journal In Organizational Psychology \& EducationalStudies, 1(2), 105-113

Agostino, M., Drago, D., \& Silipo, D. B. (2013). The Value Relevance of IFRS In The European Banking Industry. The International Journal of Accounting 48 173-217 
Alali, F. A. \& Foote, P. S. (2012). The Value Relevance of International Financial Reporting Standards: Empirical Evidence in an Emerging Market. International Journal of Accounting, 47 85-108

Alsaeed, K., (2006). The Association between Firm-Specific Characteristics and Disclosure: the case of Saudi Arabia, Managerial Auditing Journal, 21 (5), 476-496

Amir, E, Harris, T. S. \& Venuti, E. K. (1993). A Comparison of the Value Relevance of US versus non-U.S. GAAP Accounting Measures using Form 20-F reconciliations, Journal of Accounting Research, 31: 230-264.

Anandarajan, A. \& Hasan,I (2010). Value Relevance of Earnings: Evidence from Middle Eastern and North African Countries. Advances in Accounting, incorporating Advances in International Accounting: 26: 270-279

Arshad, M. A., Satar, R. A., Hussain, M., \& Naseem, M. A. (2011). Effect of Audit onProfitability: A Study of Cement Listed Firms, Pakistan. Global Journal of Management andBusiness Research, 11(9), 8-12.

Assidi, S. \& Omri, M. A (2012). IFRS and Information Quality: Cases of CAC 40 Companies. Global Journal of Management and Business Research, 12(19)

Azizi Asghar et al, (2010), The relationship between the auditing quality and profit management inthe companies accepted in the stock marke

Ball, R. \& Brown, P. (1968). An Empirical Evaluation of Accounting Income Numbers. Journal of Accounting Research. 6, 159-178.

Beaver, W. (1968). The Information Content of Annual earnings announcement, Journal of Accounting research 6, $67-92$

Beaver, W. H. (1997). Financial Reporting: An Accounting Revolution, Englewood, Cliffs, NJ. Prentice Hall.

Carmichael, D.R. (2004), The PCAOB and the social responsibility of the auditor. Accounting Horizons, 18(2), 127-133

Chalmers, K, Clinch, G \& Godfrey, J. M (2011). Changes in Value Relevance of Accounting Information upon IFRS adoption: Evidence from Australia Australian Journal of Management: 36: 151

Chandrapala, P (2011). The Value Relevance of Earnings and Book Value: The Importance of Ownership Concentration and Firm Size.

Chang, H. Chen, Y. Su, C. and Chang, Y. (2008). The Relationship between Stock Prices and EPS: Evidence Based on Taiwan Panel Data, Economic Bulletin, 3(30), 1-12.

Chen, C, Young, D. \& Zhuang, Z (2013). Externalities of Mandatory IFRS Adoption: Evidence from Cross-Border Spillover Effects of Financial Information on Investment Efficiency The Accounting Review American Accounting Association, 88(3), 881-914.

Choi, S., \& Jeter, D., (1992). The effects if qualified audit opinions on earnings response coefficients. Journal of Accounting and Economics 15: 2/3, 229-247.

Cleary, S., (1999). The relationship between firm investment and financial status. Journal of Finance, 54(2), 673-692.

Collins, D. Maydew, E, and Weiss, I. (1997). Changes in the Value-Relevance of Earnings and Book Values over the Past Forty Years. Journal of Accounting and Economics 24(1), 39-67.

Cosserat, G.W. and N. Rodda (2009), Modern auditing, $3^{\text {th }}$ ed., John Wiley \& Sons Ltd

Davis, J.H., Schoorman, F., \& Donaldson, L., (1997). Toward a stewardship theory of management. Academy of Management Review, 22(1), 20-47

Deegan, C. \& Unerman, J., (2006). Financial accounting theory, McGraw-Hill education, Maidenhead, Berkshire 
Donaldson, L. \& Davis, J.H. (1991), Stewardship theory or agency theory: CEO governance and shareholder returns. Australian Journal of Management, 16 (1), 49-65.

Eisenhardt, K.M. (1989). Agency theory: an assessment and review. Academy of management review, 14(1), 57-74.

Elder, R.J., Beasley, M.S \& Arens, M.S., (2010). Auditing and assurance services: an integrated approach: global edition, $13^{\text {th }}$ ed.Prentice-Hall, Englewood Cliffs, NJ

Fukukawa, H., and Mock, T.J., (2011). Audit risk assessments using belief versus probability. Auditing: A Journal of Practice and Theory, 30(1), 75-99.

Gee-Jung, M and Kwon, E (2009). The Value Relevance of Book Values, earnings and Cash flows: Evidence from Korea. International journal of business and management, 4(10), 28-42.

Gjerde, O. K. Knivsfla and F. Saettem (2008). The Value-Relevance of Financial Reporting in Norway. 19652004, Working Paper, February.

Glezakos, M. Mylonakis, J. \& Kafouros, C. (2012). The Impact of Accounting Information on Stock Prices: Evidence from the Athens Stock Exchange. International Journal of Economics and Finance, 4(2), $56-68$.

Hassan, M. S and Saleh, N. M (2010). The Value Relevance of Financial Instruments Disclosure in Malaysian Firms Listed in the Main Board of Bursa Malaysia, International Journal of Economics and Management 4(2): 243 - 270 (2010) ISSN 1823 - 836X

Hellman, N (2011). Soft Adoption and Reporting Incentives: A Study of the Impact of IFRS on Financial Statements in Sweden. Journal of International Accounting Research American Accounting Association 10(1): 61-83

Hellstrom, K. (2005). The Value Relevance of Financial Accounting Information in a Transitional Economy: The Case of the Czech Republic SSE/EFI Working Paper Series in Business Administration.

Hogan, C. E., and Wilkins, M. S., (2008). Evidence on the audit risk model: Do auditors increase audit fees in the presence of internal control deficiencies? Contemporary Accounting Research, 25(1), 219-242.

Hogan, C. E., and Wilkins, M. S., (2008). Evidence on the audit risk model: Do auditors increase audit fees in the presence of internal control deficiencies? Contemporary Accounting Research, 25(1), 219-242.

Jensen, M.C. \& Meckling, M.S., (1976). Theory of the firm: managerial behaviour, agency costs and ownership structure, Journal of Financial Economics, 3(4), 305-360.

Kadri, M. H., Abdul Aziz, R., Ibrahim, M. K. (2010). Value Relevance of Book Value and Earnings: Evidence from Two Different Financial Reporting Regimes. Journal of Financial Reporting \& Accounting. 7(1), 1-16.

Khanagha, J. B. (2011). International Financial Reporting Standards (IFRS) and Value Relevance of Accounting Information: Evidence from Bahrain and United Arab Emirates Stock Markets, African Journal of Social Sciences 1(1), 101-114.

Khodadadi, V and Emami, M. R. (2009). Using Panel Data Analysis Methods in Ohlson

(1995) Model to Predicting Abnormal Earnings, Euro Journals, ISSN: 1451-243X Issue 6,

Kim, O. (2013). Russian Accounting System: Value Relevance of Reported Information and the IFRS Adoption Perspective. The International Journal of Accounting 48: 525-547

Knechel, R., V. Naiker \& G. Pacheco (2007). Does industry specialization matter? Evidence from market reaction to auditor switches. Auditing: A Journal of Practice and Theory 26(1), 19-45.

Knechel, R., V. Naiker \& G. Pacheco (2007). Does industry specialization matter? Evidence from market reaction to auditor switches. Auditing: A Journal of Practice and Theory 26(1), 19-45. 
Konstantinos, P. P and Athanasios, B. P (2011). The Value Relevance of Accounting Information under Greek and International Financial Reporting Standards: The Influence of Firm - Specific Characteristics, International Research Journal of Finance and Economics, ISSN 1450-2887 Issue 76 (2011)

Kouser, R. \& Azeem, M. (2011). Relationship of Share Price With Earnings And Book Value Of Equity: Paramount Impact Of IFRS Adoption In Pakistan. Economics and Finance Review 1(8): 84 - 92,

Limperg Institute, 1932 (1985).The social responsibility of the auditor. A basic theory on the auditor's function, by Professor Theodore Limperg (1879-1961) of the University of Amsterdam, Amsterdam, The Netherlands, Limperg Institute

Lin, J. W., \& Hwang, M. I. (2010). Audit quality, corporate governance, and earningsmanagement: A meta-Analysis. International Journal of Auditing, 14(1), 57-77.

Luo, L., (2011). Are audit programs responsive to audit risk?, Doctoral thesis, University of Alberta, Canada.

Mohammadi, A. (2012). The Investigation of Relationship between Accounting Information and the Value of Companies (Case Study),

Nayeri, M. D. Ghayoumi, A. F. \& Bidari, M. A. (2012). Factors Affecting the Value Relevance of Accounting Information. International Journal of Academic Research in Accounting, Finance and Management Sciences, 2(2), 76-84.

Ohlson, J. A. (1991). The Theory of Value and Earnings and an Introduction to the Ball- Brown Analysis, Contemporary Accounting Research . 1-19

Olugbenga, A. A., \& Atanda, O. A (2014). Value Relevance of Financial Accounting Information of Quoted Companies in Nigeria: A Trend Analysis. Research Journal of Finance and Accounting 5(8)

Oyerinde, D. T. (2009). Value Relevance of Accounting Information in Emerging Stock Market: The Case of Nigeria, Proceedings of the 10th Annual Conference Repositioning African Business and Development for the 21st Century Simon Sigué (Ed.).

Oyerinde, D. T. (2011) Value Relevance of Accounting Information in the Nigerian Stock Market:, A PhD thesis in the Department of Accounting, submitted to the school of postgraduate studies, Covenant University, Ota, Nigeria.

Palea, V. (2014). Are IFRS Value Relevance for Separate Financial Statements? Evidence from the Italian stock market. Journal of International Accounting, Auditing and Taxation 23: 1-17

Pathirawasam, C. (2010). Value Relevance of Accounting Information: Evidence from Sri Lanka. International Journal of Research in Commerce \& Management, 8(1): 13-20.

Penman, S. and Sougianis, T. (1998). Comparison of Dividend, Cash Flow and Earnings Approaches to Equity Valuation, Contemporary Accounting Research 15(1), 343- 383.

Suadiye, G. (2012). Value Relevance of Book Value \& Earnings Under the Local GAAP and IFRS: Evidence from Turkey. Ege Academic Review 301-310

Subeki, M., (2010). Integrated Earnings Management, Value Relevance of Earnings and Book value of Equity, journal of Accountancy and Auditing, Indonesia, 4 (2),12-24.

Takacs, L. M. (2012). The Value Relevance of Earnings in a transition economy: evidence from Romanian stock market, Annales Universitis Apulensis series Oeconomica, 14 (1).

Tsalavoutas, I., \& Dionysiou, D. (2014). Value relevance of IFRS mandatory Disclosure Requirements. Journal of Applied Accounting Research, 15(1): 22 - 42 the International Accounting Standard Board (IASB) Framework (2011). 
Vijitha P. and Nimalathasan B. (2012), Value Relevance of Accounting Information and Share Price: A study of listed manufacturing Companies in Sri Lanka. Merit.Research Journal of Business and Management 2(1), 001-006.

Vishnani, S. and B. Shah (2008). International Differences in the Relation between Financial Reporting Decisions and Value Relevance of Published Financial Statements- with Special Emphasis on Impact of Cash Flow Reporting. International Research Journal of Finance and Economics, 17(1), $1450-2887$.

\section{Copyrights}

Copyright for this article is retained by the author(s), with first publication rights granted to the journal.

This is an open-access article distributed under the terms and conditions of the Creative Commons Attribution license (http://creativecommons.org/licenses/by/4.0/). 